\title{
O discurso da mídia televisiva na pacificação de favelas cariocas: um olhar crítico
}

\author{
Carlos Henrique Demarchi \\ https://orcid.org/0000-0002-4550-0135
}

I - UNESP.

Bauru (SP), Brasil

MENDONÇA, K.

A "pacificação" dos sentidos: mídia e violência na cidade em disputa.

Rio de Janeiro: Caravanas, 2018. 182 p.

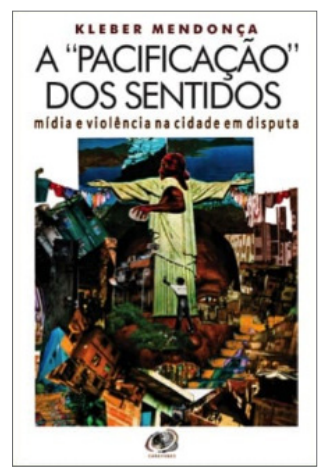

Resumo: Em A "pacificação" dos sentidos: mídia e violência na cidade em disputa, o pesquisador Kleber Mendonça analisa, a partir de edições do RJTV, como a cobertura midiática legitimou as ações do Estado no processo de pacificação de favelas cariocas. Ao empregar metodologicamente a análise do discurso, o autor revela as estratégias adotadas pela mídia para gerar consensos e silenciamentos no auge das ações de ocupação.

Palavras-chave: processo de pacificação; análise do discurso; mídia.

Abstract: The televised media discourse on the pacification of the Rio de Janeiro favelas: a critical view - In the book A "pacificação" dos sentidos: mídia e violência na cidade em disputa, researcher Kleber Mendonça analyses, from the RJTV newscast, how media coverage legitimized the actions of the State during the pacification process of favelas in Rio de Janeiro. Through discourse analysis, the author reveals the strategies adopted by the media to achieve consensus and silencing in the peak moments of the occupations.

Keywords: pacification process; discourse analysis; media.

As estratégias discursivas adotadas pelo RJTV durante a cobertura das ações de ocupação das favelas do Rio de Janeiro são tema de $A$ "pacificação" dos sentidos, o mais novo livro do professor da Universidade Federal Fluminense (UFF), Kleber Mendonça. 
Com prefácio da pesquisadora sobre a questão criminal no Brasil, Vera Malaguti Batista, a obra de 182 páginas esquadrinha as relações entre mídia e violência no período histórico que antecedeu a realização de megaeventos esportivos no Rio - Copa de 2014 e Olimpíadas de 2016.

Embora o enfoque se dê nas escolhas do discurso telejornalístico, o autor começa o livro "pelas bordas", como ele próprio diz, ao investigar nos impressos O Globo e Extra, entre 2009 e 2010, os momentos iniciais da pacificação da Vila Cruzeiro e do Complexo do Alemão.

Nesse processo de acompanhamento das transformações ocasionadas na cidade pelo projeto de ocupação policial, o primeiro capítulo compara essas intervenções com a trajetória do jogador de futebol Adriano registrada pelos diários cariocas - desde os episódios negativos de associação ao tráfico (antes da ocupação) até sua posterior visita à favela para a inauguração de projeto social (após a retomada da área pelas forças do Estado).

Para o autor, há complementaridade entre a representação discursiva adotada pela mídia e as ações pacificadoras, na medida em que a imprensa passa a focalizar os aspectos positivos da pacificação, como a chegada da paz, o acesso à cidade, a retomada de serviços essenciais na comunidade, a valorização imobiliária e a exploração de possível potencial turístico das áreas anteriormente associadas à insegurança.

A forma como três telejornais locais abordam discursivamente a chegada das forças de segurança às favelas marca o segundo capítulo. O enquadramento das reportagens e as entradas ao vivo denotam a nítida parceria mídia-Estado na pacificação das favelas. “Devemos voltar nossos olhos de análise para o que foi sendo, gradativamente, posto abaixo pelos choques de ordem e pelos aparatos militar, geográfico, publicitário e informativo da instância telejornalística" (2018, p. 65).

A presença de aspectos nas reportagens que passam facilmente despercebidos pelo telespectador não escapa da análise criteriosa do autor de "A pacificação dos sentidos", que recupera no capítulo três - "As tramas do discurso" - os resultados do acompanhamento das edições do RJTV, entre 2009 e 2012.

Por meio da análise do discurso e trazendo exemplos da cobertura realizada pelo telejornal local, o autor mostra metodologicamente os efeitos de sentido levados ao público durante a fase de ocupação e tomada da Vila Cruzeiro e do Complexo do Alemão. Nesta tarefa, consegue interpretar como a emissora, por meio do discurso de autoridade, assumiu um papel político e ideológico favorável às ações de pacificação. Da mesma forma, nota que as propostas de levar a paz às comunidades e integrar esses espaços considerados à margem da cidade carregam também conflitos, advindos dos impactos da instalação das UPPs (Unidades de Polícia Pacificadora). Essa chamada "pacificação" dos sentidos é realçada no próprio título da publicação.

No penúltimo capítulo, a intervenção do Estado na Rocinha deixa transparecer a incapacidade da mídia em compreender a complexidade das ações. As interações discursivas, explicitadas inclusive pelas falas de especialistas da área de segurança pública 
em entrevistas ao RJTV, evidenciam as opções de fala da emissora, ao passo que há o silenciamento de vozes dos moradores que poderiam contribuir para a discussão das ações em curso.

Na última parte do livro, "A interação pelas bordas", o autor reforça as implicações de casos de escolhas discursivas do telejornal em que não houve espaço para a voz crítica dos moradores da favela durante o processo de pacificação. Na análise dessas estratégias discursivas são identificados os artifícios da mídia nas reportagens para silenciar a presença de elementos autênticos e de resistência capazes de expressar a vida pulsante e a criatividade existentes nas favelas. Mesmo assim, os "saberes outros" da comunidade são apresentados e ganham amplitude, a despeito dos enquadramentos televisivos da favela como espaço "homogêneo" e da postura da empresa jornalística em reportar apenas o que é de interesse do veículo de comunicação.

Publicada pela Editora Caravanas, A "pacificação" dos sentidos é leitura indicada a alunos e professores de comunicação e também aos interessados nas intersecções entre mídia e segurança pública.

Carlos Henrique Demarchi é professor no Centro Universitário Católico Salesiano Auxilium de Araçatuba (SP) e doutorando em Comunicação na Unesp, campus de Bauru (SP).

carlos.demarchi@unesp.br

\section{Referências}

MENDONÇA, K. A pacificação dos sentidos: mídia e violência na cidade em disputa. Rio de Janeiro: Caravanas, 2018. 